\title{
STRUCTURAL CHANGES IN THE HUNGARIAN ECONOMY AND FOREIGN TRADE IN 1993-1998
}

\author{
E. VISZT and B. BORSI \\ (Received: 3 October 2000; revision received: 20 January 2001; \\ accepted: 3 April 2001)
}

\begin{abstract}
In this article, the authors give a rich-in-data account of Hungary's structural transition to a market economy between 1993 and 1998. Although the availability of statistics also puts constraint on which period to study, these years may as well be later termed the first phase of post-socialist transition. The article has three main parts. In the first, structural changes of the whole economy are presented; the structural shifts in output, value added, and investments are analysed. The diffusion of private ownership and foreign capital and the process of decentralisation and concentration are also discussed. In the second part, the manufacturing industries are in focus. With an interesting analytical tool - the growth matrix - the authors present a possible approach of studying sectoral development. By distinguishing the factor needs of the manufacturing industries, the factor intensities of production are also easy to understand and yet reasonable for studying the adjustment to modernisation trends. In the third part, the structural changes of foreign trade are shown: export orientation, import dependency, the relationship between export and technology are the main concerns of analysis. The impact of FDI on the manufacturing industries' foreign trade and performance close the third part of the article.
\end{abstract}

Keywords: foreign trade, transition, foreign investment, Hungary, Central Europe

JEL classification index: F1, F14, L, L6, L60

\section{INTRODUCTION}

As economic growth has started in Hungary, one might ask if structural changes of the recent years support this growth. The present study would like to explore the possible answers bearing in mind that in the past years the Hungarian economy was stabilised, a certain purification of the markets took place, private property became dominant and a significant amount of foreign capital flowed into the country. On the other hand, many ongoing and finished researches prove that the

Corresponding author: E. Viszt, GKI Economic Research Co., Gerlóczy u. 11, H-1052 Budapest, Hungary. E-mail: viszte@gki.hu 
relationship between industrial structure and foreign trade of the transition economies is of great interest to EU countries as well. Which branches have competitive advantage on EU and other markets? What are the factors of competitiveness? To what extent are they sustainable or vulnerable? The answers to these questions are important for both foreign investors and competitors.

In the recent years, several in-depth studies of the Hungarian economy were completed and they often include the structural changes of industry. The most detailed analysis was elaborated in the framework of an international research project, in which a new and very interesting research methodology was used (Viszt-Borsi, 1998). The study focussed on the years between 1993 and 1996. Since then, many other reports on the structural changes of the manufacturing sectors were made adding 1993-1998 data (Adler-Viszt, 1999a, 1999b). The present study is based on the results of those reports.

The paper starts the presentation of the structural transformation with the analysis of changes in the share of the main macroeconomic sectors. Output, employment, investments, ownership changes and company size are the topics we focus on.

Then the manufacturing sectors will be analysed; namely the clusters of growth, product breakdown of foreign trade, the level of technology used and import intensity. The investigations point out that companies with foreign participation play an increasingly important role in foreign trade in all industrial branches.

Such an analysis would appear to be particularly important, due to the fact that the regional orientation of foreign trade altered significantly in the 1993-1998 period. The EU's share in Hungarian exports went up to $65 \%$ from $50 \%$ and the import figures were $64 \%$ and $40 \%$ respectively. The most remarkable growth took place in the export of machinery products where the EU's share surpassed the $80 \%$ figure in 1998. The trade with the most significant trading partner, Germany, has increased considerably in 1993-1998 in both exports and imports, especially in the sectors where the weight of German capital is high.

\section{STRUCTURAL CHANGES: APPROACHING THE PATTERNS OF DEVELOPED MARKET ECONOMIES}

\subsection{Sectoral breakdown of gross output and value added}

The geographical reorientation of foreign trade started as early as the 1980s. The share of socialist and developing countries declined and the weight of developed economies increased at a slow, but reasonable pace. The process accelerated after the change of the regime. The collapse of COMECON, the treaty of accession 
with the EU (1991) and the CEFTA agreement (1993), resulted in observable changes in the foreign trade structure. In 1990 one-third and in 1996 two-thirds of export sales were realised on EU territories. Although trade relations with CEFTA countries expanded considerably, the development of trade with EU countries was more remarkable.

In the six years between 1993 and 1998, the Hungarian economy started to grow. The crisis that began in 1988 continued in 1992. Then, between 1993 and 1996, in accordance with macroeconomic stabilisation, the national economy stagnated. Observable GDP growth began only in 1997.

The different sectors showed different development patterns: the manufacturing sector had the most robust growth based on value added and gross output, and agriculture suffered the greatest setback.

Table 1

Volume indices of value added by sectors*

\begin{tabular}{|c|c|c|c|c|c|c|c|}
\hline Sector & 1993 & 1994 & 1995 & 1996 & 1997 & 1998 & 1998/1993 \\
\hline Agriculture & 93 & 98 & 103 & 104 & 100 & 99 & 96 \\
\hline Manufacturing industry & 106 & 104 & 108 & 104 & 113 & 111 & 155 \\
\hline Electricity & 110 & 104 & 100 & 99 & 99 & 99 & 111 \\
\hline Construction & 94 & 110 & 100 & 93 & 109 & 106 & 111 \\
\hline Trade & 95 & 95 & 97 & 100 & 106 & 107 & 99 \\
\hline Catering & 93 & 100 & 94 & 100 & 108 & 103 & 98 \\
\hline Transport, telecommunications & 95 & 101 & 112 & 103 & 109 & 103 & 124 \\
\hline Financial services & 115 & 130 & 82 & 100 & 104 & 95 & 121 \\
\hline Business services & 104 & 105 & 98 & 108 & 96 & 106 & 117 \\
\hline Public administration & 101 & 104 & 100 & 102 & 102 & 104 & 114 \\
\hline Education & 100 & 105 & 97 & 100 & 105 & 104 & 111 \\
\hline Health and social care & 102 & 106 & 97 & 103 & 102 & 101 & 113 \\
\hline Other communal services & 96 & 104 & 81 & 93 & 94 & 100 & 70 \\
\hline Gross Domestic Product & 99 & 103 & 102 & 101 & 105 & 105 & 115 \\
\hline
\end{tabular}

* previous year $=100 \%$

Source: National Accounts, Central Statistical Office of Hungary, Budapest (further referred as CSO).

- Robust growth of the manufacturing industry was outstanding, and it has continued since 1993. In this period value added and gross output of the manufacturing industry grew by $55 \%$ and $65 \%$, respectively.

- The agriculture could not pick up even after the moderate growth of 1994-1996. Both value added and gross output decreased by $4-5 \%$.

- According to the value added figures, growth of the construction industry was moderate (10\%). If gross output is considered, it expanded more rapidly (20\%) and its performance varied during the period. 
- The aggregate development of services lags behind the industry. Some sectors almost completely renewed, others shrank. In the whole period, performance of trade and catering among the so-called material services decreased, however, by 1997 they started to recover. Transportation has expanded since 1994 with robust, long-lasting growth. Financial services expanded by more than $20 \%$. Business services (real estate transactions, rental and leasing, consulting) have grown significantly since 1992. Gross output of education shrank in the given period. Health services developed at a slower pace (10\%) than the average.

As a result of these changes, industry remained the largest sector of the economy. Due to low material and energy use of service, its share in gross output somewhat decreased, however, its weight in value added and employment increased. Nevertheless, the number of employees in this sector did not grow either. Unlike in other countries, in Hungary the service sector was not capable to absorb the laid off workforce of other sectors in the period in question.

The services linked to the business sector developed rapidly as they tried to overcome their backwardness. Out of the traditional material services, the development of transportation and telecommunications was outstanding. Although transportation and telecommunications are classified together in aggregate statistics, there were significant differences between their development in the 1990s. Performance of transportation deteriorated more than the national economy average whereas the development of telecommunications had been outstanding even by international standards. Until the mid-90s transportation was going through the more difficult part of its transition (collapse of Eastern markets, the war in Yugoslavia, etc.). From 1997 transportation services started to stabilise their position along with the improvement in profitability and financing. However, we must not forget the tendency of differentiation between the transportation companies. Apart from road transportation, state-owned companies play dominant role in this sector, and further development of the infrastructure also depends on the government. All in all, from the point of view of EU accession, transportation is one of the most critical issues. On the other hand, telecommunications was the only sector, the output of which had grown in the first half of the 90s. Following the privatisation of the national telephone company and the passing of important laws on its regulation, the telecommunications sector saw intensive investment and development programmes. 1996 was the year of breakthrough: the number of telephone lines and output of the sector doubled as compared with the last year of the socialist regime, the number of people waiting for telephone markedly dropped, etc. The number of telephone lines per 100 inhabitants rose to 30 (1997) from 9.6 (1990). Modernisation and qualitative development of the sector was also definitely observable. 
The performance of trade declined until 1996 and improved from 1997 (so did that of catering and accommodation). Market economy would not be reality if financial services did not develop. These services (banks, insurance companies, and broker agencies) advanced quite speedily until 1994; since then they have followed a slower development path. It was criticised that the mostly state-financed education fell back and health care, which is underdeveloped, could progress only moderately.

Economic transition could take place despite that the sectors, which support the development of the human sphere, stagnated or declined. The "quasi-developed" nature of these sectors was sufficient for the structural transformation that has been implemented with significant foreign assistance (Hüttl et al., 1998). In addition, if all the advantages are taken into account (the developed state of non-market services and others), we may say that Hungary was more prepared for the economic transformation than other countries of Central and Eastern Europe. This fact added to Hungary's comparative advantages (based on cheap labour) and improved its capital absorption capacities.

\section{Table 2}

Distribution of value added by sectors between 1993 and 1998 (\%)

\begin{tabular}{|c|c|c|c|c|c|c|}
\hline Sector & 1993 & 1994 & 1995 & 1996 & 1997 & 1998 \\
\hline Agriculture & 6 & 7 & 7 & 7 & 5 & 6 \\
\hline Industry & 27 & 26 & 26 & 26 & 26 & 28 \\
\hline Construction & 5 & 6 & 5 & 4 & 4 & 5 \\
\hline Trade, catering & 13 & 13 & 13 & 13 & 12 & 12 \\
\hline Transport, telecommunications & 9 & 9 & 9 & 9 & 9 & 10 \\
\hline Other services & 39 & 41 & 40 & 40 & 44 & 40 \\
\hline Total & 100 & 100 & 100 & 100 & 100 & 100 \\
\hline
\end{tabular}

Source: National Accounts, CSO.

The weight of the main economic branches changed just slightly between 1993 and 1998 according to both the gross output and value added figures. The percentage share of industry increased and this process accelerated in 1997 and 1998. Agriculture declined and there was only a slight change in the weight of services.

\subsection{The structure of investments}

In Hungary, the period of economic crisis between 1989 and 1993 was characterised by diminishing investments. After this period of crisis investment was one of the main factors that enabled the catching up and robust growth of the restructured 
economy. The investments per GDP ratio were above $20 \%$, which is notable in international comparison as well.

The investment structure has undergone fundamental changes from many points of view. Government investments in industry almost disappeared, and industrial development has shifted towards the private sector. The aim of investments also changed: instead of adding capacities that was typical earlier, the reorganisation-restructuring type of investment became important.

The economic policy measures and the institutional reform steps also helped to alter the investment structure. Between 1992 and 1994, the improvement of capital adequacy of the banks and the inflow of foreign direct investment (FDI) resulted in a high rate of investments. From 1995, government investments slowed down as an important consequence of the introduced austerity package, and the share of investments in the manufacturing industry went up.

In the 1990s, investments flowed mainly into industries that did not develop earlier (some branches of the engineering industry, trade, telecommunications, and transportation). Construction of highways also played an important role in investments. Foreign direct investment was of great importance, especially in the manufacturing industries. The greenfield investments of foreign investors appeared first in the manufacture of motor vehicles and spare parts, while services also received substantial investments (hotels, office buildings).

The structure of investments by technological level did not change substantially during the studied six years. With respect to machine installation, foreign investments were always more significant than the domestic ones, though in some sectors the domestic efforts were also important.

As far as the function of machines is concerned, the investment in capital equipment was the most important. However, the importance of investments in data processing and telecommunications increased in the period in question. The latter investments could be realised from smaller amounts of money as well. As the volume of investments in capital equipment fell, it impeded the technological modernisation, although the first steps were taken (Szanyi-Szemlér, 1997).

There is a rather strong concentration of investments according to the company size. In 1996, more than half of investments was made by investors who invested more than 1 billion HUF, however, their percentage share in the number of investors was only 2.1\% (Molnár-Skultéty, 1999).

The less developed nature and the demand for catching up of the Hungarian economy (and those of the services) explain the shift of investments towards services in the 1990s. A huge lag had to be overtaken in telecommunications, trade and other fields of the infrastructure. 
Table 3

Distribution of investments by the main sectors of the Hungarian economy (\%)

\begin{tabular}{|c|c|c|c|c|c|c|}
\hline Sector & 1993 & 1994 & 1995 & 1996 & 1997 & 1998 \\
\hline Agriculture & 3.1 & 2.9 & 2.6 & 3.1 & 3.6 & 3.7 \\
\hline Mining & 0.5 & 0.5 & 0.4 & 0.3 & 0.3 & 0.3 \\
\hline Manufacturing industry & 20.4 & 19.3 & 21.8 & 23.5 & 23.2 & 26.1 \\
\hline Electricity & 8.4 & 8.9 & 8.9 & 7.1 & 6.7 & 7.2 \\
\hline Industry & 29.4 & 28.7 & 31.1 & 30.9 & 30.3 & 33.6 \\
\hline Construction & 1.8 & 1.9 & 1.6 & 2.1 & 1.7 & 1.9 \\
\hline Trade & 5.8 & 5.2 & 4.7 & 7.9 & 6.4 & 7.1 \\
\hline Catering & 1.1 & 0.9 & 0.8 & 0.8 & 1.0 & 0.5 \\
\hline Transport, telecommunications & 18.3 & 21.0 & 19.2 & 16.2 & 19.0 & 18.9 \\
\hline Financial services & 4.7 & 4.2 & 5.2 & 3.3 & 2.5 & 3.4 \\
\hline Business services & 21.1 & 19.8 & 22.7 & 24.3 & 22.5 & 18.1 \\
\hline Public administration, social security & 4.2 & 4.5 & 3.7 & 3.0 & 3.9 & 3.6 \\
\hline Education & 2.8 & 2.4 & 1.5 & 2.2 & 2.2 & 1.9 \\
\hline Health care & 3.8 & 3.8 & 3.4 & 2.4 & 2.6 & 2.5 \\
\hline Public administration & 4.0 & 4.7 & 3.6 & 3.8 & 4.5 & 4.8 \\
\hline Total & 100 & 100 & 100 & 100 & 100 & 100 \\
\hline
\end{tabular}

Source: Statistical Yearbook 1993-1998, CSO.

Investment activities are more and more dominated by organisations, which have foreign interest. There are two factors behind this fact: on the one hand the weight of foreign capital increases as privatisation progresses and on the other, the settled foreign firms also started to invest in new projects (GKI, 1998).

\subsection{Diffusion of private ownership and foreign capital}

Foreign investors were important actors in the organisational transition of the Hungarian economy. There were 6000 companies with foreign capital in 1990 and by 1998 their number went up to 26,000: half of them were owned exclusively by foreigners.

In 1998, most of the foreign companies concentrated in trade $(11,726$ companies registered), business services (4531), hotels (1056), construction (1069) and engineering industry (1009). The majority of the foreign firms concentrated in the abovementioned branches already in 1993. More than one-fourth of the foreign companies in the manufacturing industry belongs to the engineering industry, but their number is also significant in the food industry, manufacture of apparel, wood and chemical products. Within industry, the largest amount of foreign capital was invested in the energy sector. Its weight is well illustrated by the 7 billion HUF of foreign capital per company figure, which is the multiple of the industrial average. 
Table 4

Number and registered capital of companies with foreign owner(s), 1993-1998

\begin{tabular}{lcccc}
\hline Sector & $\begin{array}{c}\text { Number of } \\
\text { companies } \\
\text { with foreign } \\
\text { interest, 1998 }\end{array}$ & $\begin{array}{c}\text { Registered } \\
\text { capital } \\
\text { (billion HUF), }\end{array}$ & $\begin{array}{c}\text { Change in the } \\
\text { number of } \\
\text { foreign owned } \\
\text { companies, } \\
1998\end{array}$ & $\begin{array}{c}\text { Change of } \\
\text { foreign } \\
\text { registered } \\
\text { capital, } \\
1998 / 93(\%)\end{array}$ \\
\hline Agriculture & & & $179)$ & 272 \\
Mining & 839 & 21.8 & 140 & 128 \\
Manufacturing industry & 76 & 11.5 & 104 & 268 \\
Food industry & 3,996 & 888.8 & 96 & 207 \\
Textile, apparel & 476 & 229.8 & 119 & 302 \\
Wood, paper & 590 & 43.3 & 98 & 219 \\
Chemical industry & 647 & 48.8 & 97 & 466 \\
Construction material & 383 & 172.9 & 100 & 203 \\
Metallurgy, fabricated metal & 170 & 57.1 & 100 & 322 \\
Engineering industry & 515 & 74.0 & 266 & 278 \\
Electricity, gas, heat, etc. & 1,009 & 253.8 & 98 & 6,714 \\
Construction & 48 & 335.7 & 116 & 170 \\
Trade & 1,069 & 44.3 & 125 & 314 \\
Lodging and catering & 11,726 & 283.4 & 109 & 164 \\
Transportation & 1,056 & 42.5 & 131 & 287 \\
Financial services & 819 & 166.5 & 156 & 536 \\
Real estate, business services & 181 & 257.7 & 119 & 473 \\
Education & 4,531 & 266.2 & 119 & 166 \\
Health care & 153 & 0.5 & 125 & 171 \\
Total & 155 & 2.4 & & 356 \\
\hline
\end{tabular}

Source: Foreign Direct Investments in Hungary, 1993 and 1998, CSO.

In the years between 1993-1998, one of the most important structural changes was the growing concentration of foreign capital: the amount of registered foreign capital multiplied by more than three times (at current prices) as compared with the number of companies with foreign capital, which multiplied only by 1.3. Out of the manufacturing sectors, the increase of concentration was remarkable in the chemical industry. Investments in the food industry and construction expanded less than the average (at real prices). There were substantial resources invested in the manufacture of machinery (in this sector there was a significant amount of foreign capital as early as 1993). Agriculture and mining still cannot attract substantial foreign investments. In the course of privatisation, the energy sector absorbed significant amounts of foreign capital.

As far as services are concerned, the growth rate of foreign investment was substantially higher than in the case of the manufacturing industry. The targeted areas of foreign capital included trade, transportation, telecommunications, financial and business services. Due to the bank privatisation, financial services attracted most of the foreign capital. 


\subsection{Decentralisation and concentration of the company structure by size}

In Hungary, enterprises had been highly concentrated before the change of the regime. The number of companies started to rise as early as the 1980 s, then the political change brought about another boom in the establishment of new companies. Organisational structure of the economy has changed along two processes:

- as a result of decentralisation and privatisation of the over-centralised economy, and

- as a consequence of the domestic and the more significant foreign investments and company foundations.

Table 5

Number and distribution of companies by number of employees

\begin{tabular}{lrrrr}
\hline \multirow{2}{*}{ Employment } & \multicolumn{2}{c}{1993} & \multicolumn{2}{c}{1998} \\
\cline { 2 - 5 } & Number & $\%$ & Number & $\%$ \\
\hline Less than 21 people & 68,219 & 82 & 134,380 & 92 \\
21-50 people & 7,637 & 9 & 6,366 & 4 \\
$51-300$ people & 6,055 & 7 & 8,645 & 3 \\
More than 300 people & 1,624 & 2 & 146,279 & 0.6 \\
Total & 83,535 & 100 & 100 \\
\hline
\end{tabular}

Source: Statistical Yearbook 1993 and 1998, CSO.

The most striking change is that the number of both the incorporated businesses and of the small-size companies roughly doubled. If we take into account economic associations, which have no legal entity, the expansion of small businesses was twice as much. The number of medium-sized companies, however, dropped by $23 \%$, and that of large businesses fell to its half.

In Western European comparison, the number per capita of enterprises in Hungary does not differ too much from the patterns of developed countries. However, the difference is huge with respect to the average capital stock, technological level and profitability.

If turnover is also taken into account, we may see signs of concentration according to company size. The weight of companies that have high turnover and export was increasing markedly in the past $3-4$ years, especially in the engineering industry. In 1997, for instance, more than one-third of the increase of industrial output was the result of rising production in the ten largest industrial companies. In 1997 the mentioned ten companies accounted for $22 \%$ of the industrial output (17\% in the previous year). They include three car manufacturers and a 
computer and telecommunications products manufacturing company. The others are large old companies of the Hungarian industry, in which foreign capital also plays an important role.

The export activity depends on company size as well. In 1992, the weight of exports in total sales was $8.5 \%$ in small enterprises, $10 \%$ in medium-sized firms and $16 \%$ in large companies. In 1997 the corresponding figures were $7.5 \%, 15 \%$ and $30 \%$ (ECOSTAT, 1998).

\section{STRUCTURAL CHANGES \\ IN THE MANUFACTURING INDUSTRIES}

\subsection{The growth and decline of industrial branches}

Industrial output fell sharply in 1990-1991, followed by stagnation in 1992-1993. Since 1993, the industrial output has continuously grown.

Export played the main role in the growth of industrial output since 1994. From that time, the export growth reaches two-digit annual figures. The high growth rates of exports in the five years elapsed mean long-lasting upswing. Domestic sales increased only slightly in 1993-1998, moreover, they dropped in 1995-1997. The low rate of increase of domestic sales is explained by contracting domestic consumption on the one hand. On the other hand, however, the crowding-out effect of import was also considerable. The domestic market share of the Hungarian industry dropped between 1993 and 1998 from 57\% to 42\%. In every industrial branch the percentage share of domestic markets decreased in the discussed period.

Table 6

Share of the domestic market in the sale of selected Hungarian industries (\%)

\begin{tabular}{lcc}
\hline Sector & 1993 & 1998 \\
\hline Food industry & 88 & 84 \\
Manufacture of apparel & 35 & 20 \\
Wood, paper and printing & 66 & 53 \\
Chemical products & 56 & 45 \\
Non-metallic mineral products & 77 & 60 \\
Metallurgy & 58 & 40 \\
Engineering industry & 28 & 14 \\
Industry total & 57 & 42 \\
\hline
\end{tabular}

Source: From Socialism to Capitalism in Hungary, GKI Co. Budapest. 
The fast growth of the Hungarian industry between 1993 and 1998 was accompanied by pronounced shifts towards certain industrial branches as a result of the different growth rates in the different sectors.

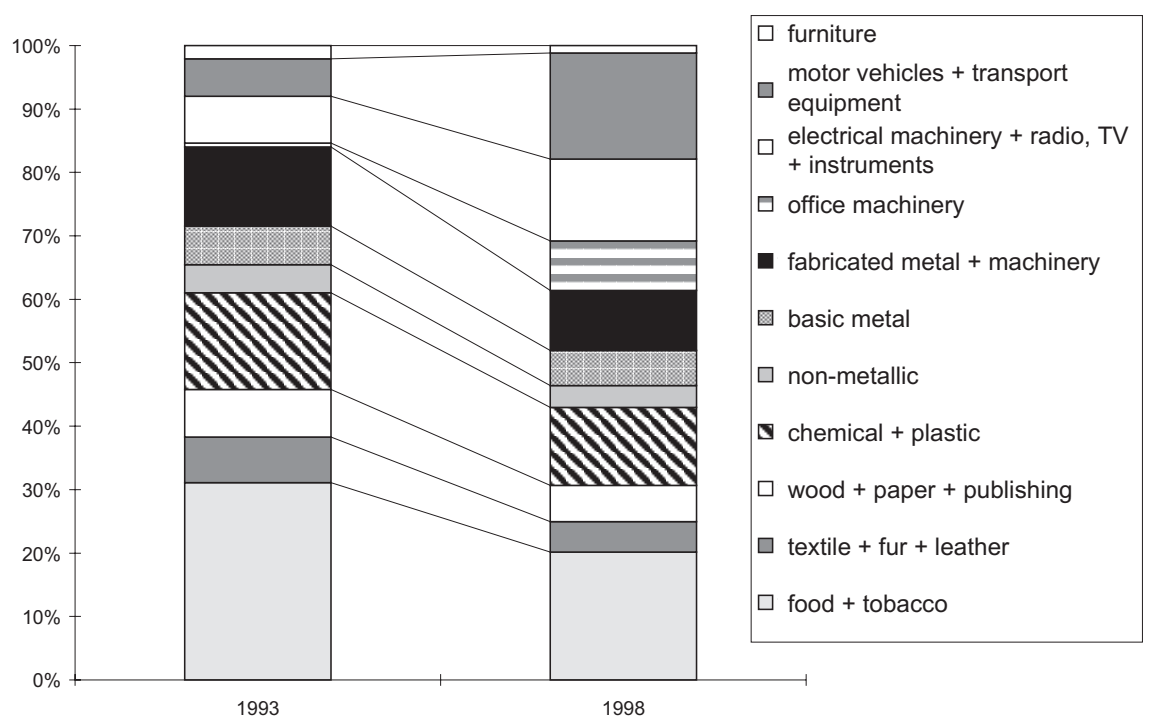

Figure 1. Share of the branches in manufacturing output

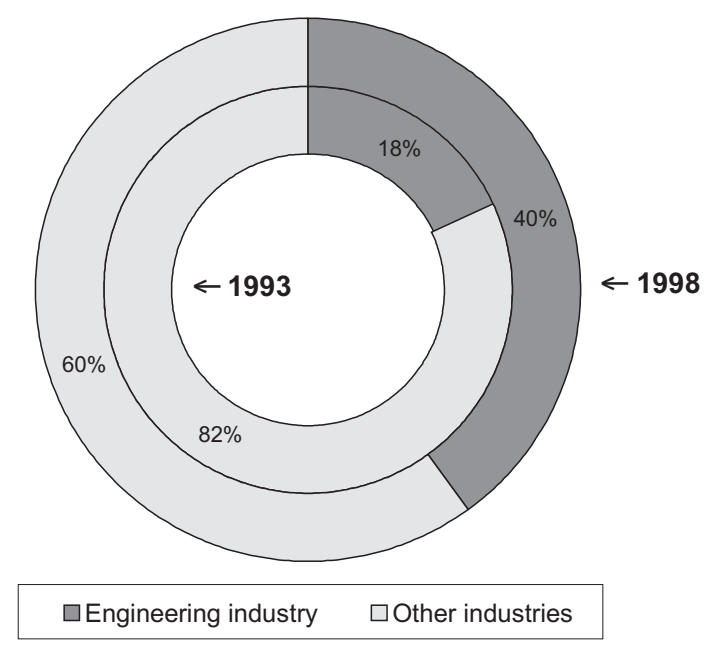

Figure 2. Share of engineering industry in the output of the manufacturing industry 
Only a few sectors contracted (the food, textile, leather and the chemical industries), others performed somewhat above the average in terms of output growth (the plastic and basic metal industries), while certain sectors boosted, multiplying their output.
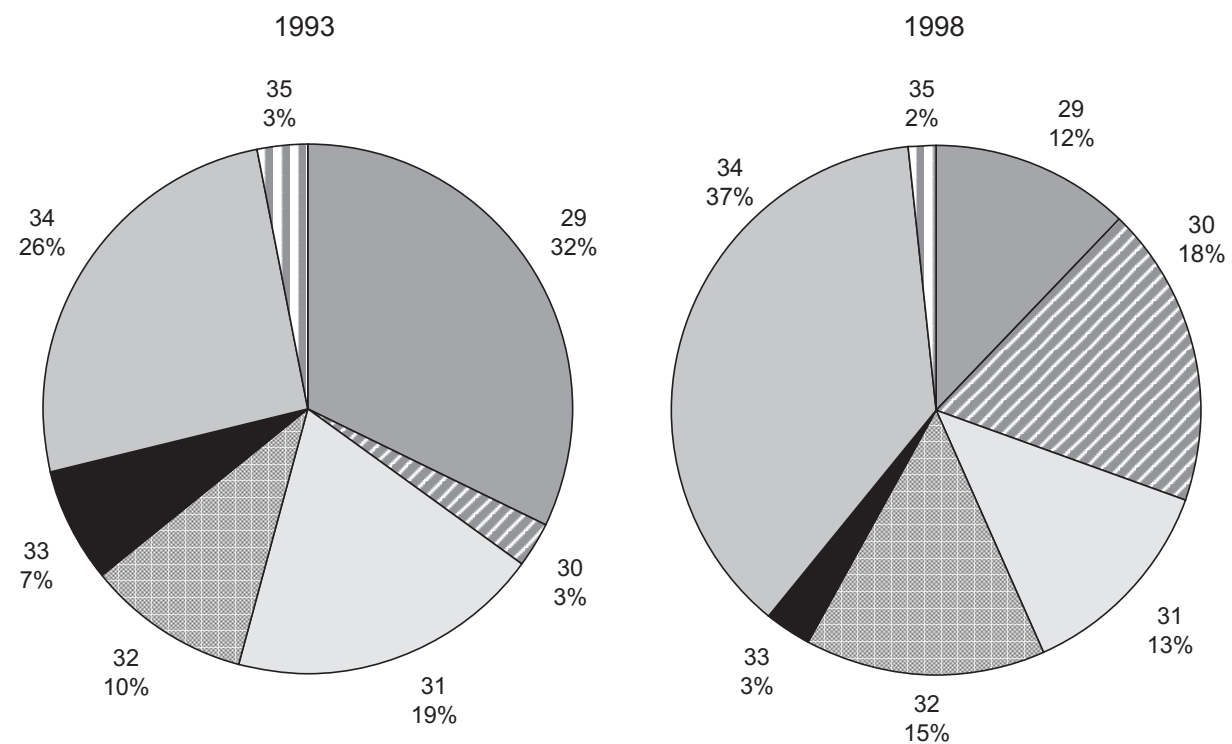

29 General purpose machinery, 30 Office machinery, 31 Electrical equipment, 32 Radio, TV, 33 Precision instruments, 34 Motor vehicle, 35 Other transport equipment

Figure 3. Share of the subsectors in the output of the engineering industry

More detailed analyses (with the use of three- or four-digit data of the industrial classification) can show the process of restructuring in a more detailed picture. Some branches of the engineering industry (manufacture of motor vehicles, manufacture of parts and accessories for motor vehicles and their engines, manufacture of lighting equipment and electric lamps, office machinery) have been the engines of growth of the Hungarian manufacturing industry. The percentage share of industries related to the manufacture of computers (office machinery and telecommunications equipment) increased the most dynamically. Subsequently, the structure of industrial production and exports changed significantly. By 1998 the proportion of production of the computer-related subsectors in the Hungarian manufacturing industry surpassed $10 \%$, which ratio is similar to that of the EU countries. 
Between 1993 and 1998 the following subsectors declined in terms of output, showing the negative effects of restructuring: preparation and spinning of textile fibers; textile weaving, dressing and dyeing of fur; manufacture of articles of fur, tanning and dressing of leather, manufacture of luggage, handbags, saddlery and harness, manufacture of footwear, manufacture of refined petroleum products, manufacture of other chemical products, forging, pressing, stamping and rollforming of metal, powder metallurgy, treatment and coating of metals, general mechanical engineering on a fee or contract basis, manufacture of accumulators, primary cells and primary batteries, building and repairing of ships and boats, manufacture of aircraft and spacecraft, manufacture of motorcycles and bicycles, manufacture of furniture.

\subsection{Growth clusters in the manufacturing industry}

In order to explore the restructuring process of the industry in detail, we can use the growth matrix concept. This method is based on the segmentation of industrial branches according to size and growth rate. Accordingly, the growth or contraction of large sectors has the greatest influence on industrial performance. The matrix was constructed in the following way:

Table 7

The growth matrix

\begin{tabular}{|c|c|c|c|c|}
\hline \multirow{3}{*}{\multicolumn{2}{|c|}{$\begin{array}{l}\text { Growth rate of output } \\
\text { between } 1993 \text { and } 1998\end{array}$}} & $\begin{array}{l}\text { Large } \\
>1 \%\end{array}$ & $\begin{array}{c}\text { Average } \\
0.5-1 \%\end{array}$ & $\begin{array}{c}\text { Not significant } \\
<0.5 \%\end{array}$ \\
\hline & & \multicolumn{3}{|c|}{$\begin{array}{l}\text { Subsectors, according to the weight of their output } \\
\text { in the manufacturing industry total }\end{array}$} \\
\hline & & A & $\mathrm{B}$ & $\mathrm{C}$ \\
\hline 1. Outstanding & $>180 \%$ & $1 \mathrm{~A}$ & $1 \mathrm{~B}$ & $1 \mathrm{C}$ \\
\hline 2. Above average & $140-180 \%$ & $2 \mathrm{~A}$ & $2 \mathrm{~B}$ & $2 \mathrm{C}$ \\
\hline 3. Average & $100-140 \%$ & $3 \mathrm{~A}$ & $3 \mathrm{~B}$ & $3 \mathrm{C}$ \\
\hline 4. Declining & $<100 \%$ & $4 \mathrm{~A}$ & $4 B$ & $4 \mathrm{C}$ \\
\hline
\end{tabular}

Source: Calculations based on corporate balance sheets, CSO's database.

Based on the 1993 and 1998 statistics, Table 8 shows the 1998 distribution of output in the breakdown of growth rates and sectoral weights.

Half of the manufacturing industry total was the output of the outstandingly growing subsectors, and the declining sub-branches accounted for the one-fifth of the total output. The concentration of output and growth therefore is very high: large subsectors (A) produced $65 \%$ of the manufacturing industry's output in 1998. 
Table 8

Distribution of total output by size and by rate of growth (\%)

\begin{tabular}{lrrrr}
\hline Growth rate & A & B & C & Total \\
\hline 1. Outstanding & 40 & 4 & 5 & 49 \\
2. Above average & 3 & 2 & 3 & 8 \\
3. Average & 10 & 9 & 4 & 23 \\
4. Declining & 12 & 3 & 5 & 20 \\
Total & 65 & 18 & 17 & 100 \\
\hline
\end{tabular}

Source: see Table 7.

The distribution of domestic sales is much more balanced in the growth matrix. Almost the same percentage share of the domestic sales was produced in the declining subsectors as in the outstandingly growing ones. Small-sized subsectors also played a more considerable role in domestic output than in the total output.

The weight of export sales was significant in all categories of the growth matrix, even in the declining subsectors. The percentage share of export sales declines together with the size (and importance) of the industries. $75 \%$ of industrial exports is performed by the large subsectors.

Table 9

Share of exports in the total output (\%)

\begin{tabular}{lccc}
\hline Growth rate & A & B & C \\
\hline 1. Outstanding & 72 & 59 & 45 \\
2. Above average & 50 & 44 & 44 \\
3. Average & 52 & 33 & 30 \\
4. Declining & 33 & 30 & 42 \\
\hline
\end{tabular}

Source: see Table 7.

In the recent years, large and outstandingly growing (A1) subsectors gained considerably in number. As IKIM ${ }^{1}$ investigations showed, in 1993 there were 5 subsectors in this category, compared to 11 in 1998. In 1993-1998 the large and outstandingly growing subsectors of the manufacturing industry include the manufacture of computers; motor vehicles; manufacture of radio, television and communication equipment; manufacture of parts and accessories for motor vehicles; plastic products; and metallurgy. Most of these subsectors fell in the same category in 1995 as well, but since then new growth clusters have also appeared as a

1 Ministry of Industry, Trade and Tourism (renamed as of July 1998 Ministry of the Economy). 
result of considerable new capacities and successful privatisation (manufacture of aluminum products, manufacture of computers). The latter started from almost zero and became the second largest subsector of the manufacturing industry (manufacture of motor vehicles being the first). Other subsectors (manufacture of bulb and lighting equipment; manufacture of finished metallurgical products; plastic products) came from the second largest category $(2 \mathrm{~A}$ - large and growing faster than the average) after performing high growth rates.

In 1995 the large and outstandingly growing subsectors covered $14 \%$ of the output. This figure went up to $36 \%$ by 1998 . The growth clusters mainly include the engineering industry subsectors, however, some extent of diversification can also be shown with respect to the growing and significant subsectors (aluminium industry, plastic products, metallurgy).

The percentage share offoreign capital in the registered capital is much higher in this category, especially in the export-oriented subsectors, than in the manufacturing industry average. The mentioned subsectors provide work for one-fourth of the people employed in the manufacturing industry, and the production is highly capital-intensive.

The following large industries decline: the processing of meat, fish and poultry; manufacture of prepared animal feeds; bakery products; manufacture of sugar; and pharmaceuticals ( $30 \%$ decrease of output). The explanation is manifold: the Russian crisis (meat and pharmaceuticals), troubles in agriculture (animal feed), large and unnecessary capacities (bakery products).

\subsection{Structural changes of industry with respect to the factor intensities of production}

Structural changes of industry between 1993 and 1998 can be shown through the changes in the factor intensities of production. In the discussed period the industries that are innovative and technology-intensive, definitely gained importance. This observation is in line with the results concluded from the growth matrix concept, which correspond to that most of the growing industries are innovative and technology-intensive.

The industrial branches were divided into five groups, according to the factor intensities: ${ }^{2}$

2 We should mention that there can be other classifications. Later in this study, we present another (simpler and somewhat different) categorisation. For the below given classification see (Adler-Viszt, 1999b). 
I. Labour-intensive industries: textile, apparel, footwear, other industry.

II. Raw-material-intensive industries: mining, paper, mineral oil, furniture, energy.

III. Industries based on traditional technologies: paper, publishing, non-metallic mineral products, metallurgy, fabricated metal products.

IV. Industries based on technology development and wide supplier network: chemical fibers, rubber and plastic products, electrical machinery, spare parts and accessories for motor vehicles.

$\mathrm{V}$. Industries based on innovative technology development: manufacture of basic chemicals, machinery and equipment, office machinery and computers, precision instruments, source of light, radio, television and communication equipment, motor vehicles.

We used the data of corporate tax return sheets and derived the above groups.

Table 10

Corporate tax return in the five industrial branches

\begin{tabular}{|c|c|c|c|c|}
\hline & \multicolumn{2}{|c|}{$\begin{array}{l}\text { I. Labour-intensive } \\
\text { industries }(\%)\end{array}$} & \multicolumn{2}{|c|}{$\begin{array}{c}\text { II. Raw-material-intensive } \\
\text { industries }(\%)\end{array}$} \\
\hline & 1993 & 1998 & 1993 & 1998 \\
\hline Number of companies & 26 & 25 & 10 & 12 \\
\hline Net turnover & 27 & 22 & 34 & 26 \\
\hline Export & 27 & 17 & 9 & 6 \\
\hline \multirow[t]{3}{*}{ Employment } & 34 & 32 & 19 & 18 \\
\hline & \multicolumn{2}{|c|}{$\begin{array}{l}\text { III. Industries based } \\
\text { on traditional } \\
\text { technologies }(\%)\end{array}$} & \multicolumn{2}{|c|}{$\begin{array}{c}\text { IV. Industries based on technology } \\
\text { development and wide } \\
\text { supplier network }(\%)\end{array}$} \\
\hline & 1993 & 1998 & 1993 & 1998 \\
\hline Number of companies & 29 & 32 & 9 & 9 \\
\hline Net turnover & 15 & 15 & 5 & 8 \\
\hline Export & 19 & 11 & 9 & 12 \\
\hline \multirow[t]{3}{*}{ Employment } & 19 & 18 & 7 & 9 \\
\hline & \multicolumn{4}{|c|}{$\begin{array}{l}\text { V. Industries based on innovative } \\
\text { technology development }(\%)\end{array}$} \\
\hline & \multicolumn{2}{|r|}{1993} & \multicolumn{2}{|c|}{1998} \\
\hline Number of companies & \multicolumn{2}{|r|}{26} & \multicolumn{2}{|c|}{23} \\
\hline Net turnover & \multicolumn{2}{|r|}{18} & \multicolumn{2}{|c|}{30} \\
\hline Export & \multicolumn{2}{|r|}{36} & \multicolumn{2}{|c|}{54} \\
\hline Employment & \multicolumn{2}{|r|}{21} & \multicolumn{2}{|c|}{23} \\
\hline
\end{tabular}


In the table below, we summarised some of the results: the structural change in sales, export and the number of staff:

Table 11

Percentage change in sales, exports and staff (1998/1993)*

\begin{tabular}{cccr}
\hline & Sales & Export & Staff \\
\hline I. & 268 & 366 & 80 \\
II. & 251 & 427 & 84 \\
III. & 314 & 358 & 80 \\
IV. & 498 & 803 & 116 \\
V. & 543 & 878 & 94 \\
Total & 331 & 597 & 86 \\
\hline
\end{tabular}

* At current HUF prices.

- The industries that require intensive technology development and large amount of supplies and the innovative industries performed an outstanding growth of sales. Labour- and raw-material-intensive industries lag behind the average.

- Concentration of the companies increased, especially in the two "most modern" groups.

- Share of the sectors that require innovative technology (IV and V) rose considerably both in sales and exports. The significance of raw-material- and labour-intensive industries declined in both relations.

- Export competitiveness improved in all branches. The improvement was highly above the average in the modern technology-intensive industries. The output growth was export-led in the technology-intensive sectors.

- The net sales per capita (productivity) increased more than the staff number (the sales figures were adjusted with the price changes). This development was remarkable in the industries that need suppliers and innovative technology.

Innovation plays an important role in economic growth as it was also shown by Papanek et al. (1998). There is an obvious correlation between $R \& D$ intensity (high-tech characteristic) and the growth of export volumes in the manufacturing subsectors. When the R\&D intensity of exports to EU countries was examined, the same relationship proved to be mathematically stronger.

The calculations also showed that there is a significant relationship between the sectoral weight of foreign capital and the sector's export orientation. Moreover, foreign capital proved to be the most significant explanatory variable of export orientation. The correlation calculus also threw spotlight on the importance of the relationship between foreign capital, profitability, liquidity and output per capita. 


\section{CHANGES IN THE STRUCTURE OF TRADE}

\subsection{Towards a strong specialisation}

It is a widely shared opinion that exports from Central and Eastern European Countries (CEECs) are more and more specialised (Dobrinski, 1996). At the beginning of the 1990s, the CEECs specialised for the export of the so-called sensitive products (steel, textile), and the export of machinery products was not significant anymore because of the collapse of COMECON trade. As import is concerned, chemical and machinery products had been targeted, but the weight of machinery products has risen in many CEECs since 1996. The diversification of exported machinery goods can also be shown.

If the structural changes of foreign trade are studied, we observe that the intra-industry trade has become more important in the trade relations of the EU and the CEECs. In the case of Hungary, not only a modern branch (engineering industry) can export more and more to the developed countries, but more and more of its subsectors can stand the competition on international markets. Hungary's comparative advantages fundamentally changed, and the Hungarian economy's competitiveness is no longer found in the labour-and natural-resource-intensive sectors. Foreign capital was of outstanding importance as it enabled the rapid development of capital and technology-intensive industries.

Table 12

The TOP 10 product groups in the Hungarian exports (\%)

\begin{tabular}{lrlr}
\hline \multicolumn{1}{c}{1993} & & & 1998 \\
\hline Product groups & $\%$ & Product groups & $\%$ \\
\hline Wearing apparel & 11.3 & Energy generators & 12.1 \\
Electrical machine & 6.3 & Electrical machine & 10.8 \\
Meat and meat products & 6.2 & Office machinery & 10.6 \\
Motor vehicles & 5.4 & Telecommunications products & 7.5 \\
Cereals and cereal products & 5.0 & Motor vehicles & 6.1 \\
Fruits, vegetables & 4.5 & Wearing apparel & 5.5 \\
Plastic products & 3.8 & Meat and meat products & 2.9 \\
Iron and steel & 3.3 & General purpose machinery & 2.6 \\
Mineral oil products & 3.1 & Metal products & 2.5 \\
Pharmaceuticals & 2.8 & Non-ferrous metals & 2.2 \\
Total & 52 & Total & 63 \\
\hline
\end{tabular}

Source: Foreign Trade Statistics Yearbooks, CSO. 
Out of the TOP 10, five product groups were the same in 1993 and 1998. However, the ranking and the shares had changed considerably. Machinery products took over the leading positions so that by 1998 their share increased to $52.2 \%$ from the $11.7 \%$ in 1993.

Table 13

The TOP 10 product groups in the Hungarian imports (\%)

\begin{tabular}{lclr}
\hline \multicolumn{1}{c}{1993} & & & 1998 \\
\hline Product groups & $\%$ & Product groups & $\%$ \\
\hline Petroleum and petroleum products & 8.6 & Electrical machines & 10.8 \\
Motor vehicles & 6.0 & Motor vehicles & 7.0 \\
Textile fibers, textile & 5.6 & Energy generators & 6.5 \\
Electrical machines & 5.2 & Telecommunications equipment & 6.1 \\
Natural and artificial gases & 4.0 & Office machinery & 5.9 \\
Professional machines & 3.9 & General purpose machinery & 5.8 \\
Paper products & 3.0 & Textile fibers, textile & 4.5 \\
Iron and steel & 2.8 & Metal products & 3.3 \\
Pharmaceuticals & 2.6 & Natural and artificial gases & 2.9 \\
Organic chemicals & 2.5 & Petroleum and petroleum products & 2.9 \\
Total & 44 & Total & 56 \\
\hline
\end{tabular}

Source: Foreign Trade Statistics Yearbooks, CSO.

Engineering industry made a considerable growth in imports, too: its percentage share was only $15 \%$ in 1993 and by 1998 it went up to $42 \%$ in the TOP 10 . Seven groups of the TOP 10 export and import product groups belonged to the manufacture of machinery both in 1993 and 1998. Intra-industry trade became characteristic in the Hungarian foreign trade, similarly to the trade patterns of developed economies.

In an international comparative analysis of foreign trade, Lemoine and Freudenberg were investigating the comparative advantages of the CEECs (Lemoine-Freudenberg, 1998). The authors showed that many subsectors of the engineering industry gained comparative advantage not only in Hungary, but in Poland (electrical machinery, telecommunications, medical instruments), the Czech Republic (electrical machinery, manufacture of other transportation equipment, telecommunications) and Slovenia (manufacture of machines and machinery equipment, electrical machinery, office machinery and computers) as well. Consequently, the similar development patterns enabled the development of the same directions of specialisation. 
As a result, competition intensifies on the EU markets of some engineering industry products between the CEECs (e.g. electrical motors, cables, and lighting equipment). With respect to foreign trade, the strongest Hungarian industry is the manufacture of motor vehicles, which was negligible before, and the development of electrical machinery, energy generators and computers is also promising. Similar patterns of foreign trade evolved in other CEFTA countries, where the strongest branches are among the non-traditional industries:

- In the industries, which had a comparative advantage before (textile industry, metallurgy), the advantage diminished even if it remained an advantage. This corresponds to the exhaustion of export competitiveness. (With respect to the manufacture of apparel and other labour-intensive sectors, we would not say that there are no reserves, but as a consequence of increasing labour costs, the production shifted towards the East - outward processing at cheaper costs).

- In line with the fast export growth, the improving comparative advantages may enable some industries to become export leaders. In Hungary these industries include the manufacture of office machinery and computers, radio and TV sets. Manufacture of motor vehicles can boost in Slovenia and Slovakia, and more machinery sectors are promising in the Czech Republic.

Notably, in the industries where export grows, import also does. The international division of labour seems to be more and more significant between the companies of Eastern and Western Europe. Intra-industry trade is regarded as a sign of close integration, whereas exports of raw materials, energy and simple-processed goods are usually associated with the inferior position of international trade. Djankov and Hoekman found that the only significant factor that explained the development of intra-industry trade was the level of FDI (Djankov-Hoekman, 1996).

In transition countries intra-industry trade very often means intra-firm trade. Intra-industry trade may also mean trade among economically dependent, but legally distinct firms. This may be the case with the multinationals' traditional supplier networks, as well as with outward processing by Central European firms for multinational companies. Éltetó and Sass found that a high share of FDI-related intra-industry trade occurs in the case of highly complex manufactures of R\&D intensive goods. Standardised goods of a medium or low R\&D content are manufactures rather in outward processing based on cost advantages.

An important result of the international comparative analyses is that the export structures of the CEECs are very similar to one another and they are getting 
more and more similar. This predicts a fierce competition between the potential candidates of the EU's enlargement. Foreign companies have considerable control in the following industries of the CEFTA countries: manufacture of motor vehicles, rubber and plastic products, electrical machinery and telecommunications. Intra-industry trade is very significant in all the mentioned sectors. At the same time, the export structure of the second-round candidates (the Baltic states, Bulgaria, Romania) probably remains strongly linked to the traditional industries.

In the CEECs, including Hungary, vertical specialisation characterises some of the industries; i.e. only certain production stages are carried out in the country, others are implemented in other countries. Export and import of intermediary goods and semi-finished products are substantial in foreign trade. The fast growth of foreign trade between Western and Eastern Europe is highly associated with the presented segmentation of production processes.

Vertical integration is very strong in five industries within the framework of outward processing traffic and the international division of labour in the companies that settled in the CEECs: manufacture of textile and wearing apparel, leather and footwear, office machinery and computers, telecommunications and motor vehicles. In Hungary, the export of these branches constitutes roughly half of the total exports.

\subsection{The contribution of exports to output growth}

The growth of the Hungarian manufacturing sectors was definitely export-led in the 1990s, because domestic consumption decreased. Except for one sector (publishing and printing), all the others exported more in 1998 than in 1993. In 1998 about half of the industrial production was exported as compared with 1993, when the same figure was only $24 \%$. The export share in total output is still increasing.

Export growth was general across industry. While in 1993 motor vehicle, electrical machinery and the textile industry were the leading sectors in exports, in 1998 office machinery, motor vehicles and telecommunications equipment were the most successful subsectors on the export markets. In the case of the manufacture of office machinery and motor vehicles the export share was more than $90 \%$ of the subsectoral output and in the case of electrical machinery and telecommunications equipment it was more than $80 \%$. In these subsectors output growth multiplied in the 1993-1998 period, leaving behind all the others. 
Table 14

Export per output ratios in the manufacturing sectors (\%)

\begin{tabular}{|c|c|c|c|c|c|c|c|}
\hline $\begin{array}{l}\text { NACE } \\
\text { code }\end{array}$ & $\begin{array}{l}\text { Industry } \\
\text { (short name) }\end{array}$ & 1993 & 1994 & 1995 & 1996 & 1997 & 1998 \\
\hline 15 & Food & 15 & 16 & 19 & 21 & 24 & 23 \\
\hline 16 & Tobacco & 2 & 8 & 11 & 20 & 12 & 9 \\
\hline 17 & Textile & 37 & 45 & 48 & 48 & 50 & 56 \\
\hline 18 & Dressing and dyeing of fur & 61 & 66 & 72 & 72 & 70 & 70 \\
\hline 19 & Leather & 49 & 49 & 55 & 58 & 62 & 63 \\
\hline 20 & Wood & 21 & 24 & 30 & 33 & 39 & 44 \\
\hline 21 & Paper & 9 & 14 & 17 & 19 & 26 & 28 \\
\hline 22 & Publishing and printing & 4 & 4 & 5 & 4 & 4 & 4 \\
\hline 24 & Chemical & 41 & 42 & 46 & 37 & 49 & 50 \\
\hline 25 & Plastic & 32 & 35 & 38 & 42 & 44 & 42 \\
\hline 26 & Non-metallic mineral & 21 & 20 & 21 & 23 & 26 & 31 \\
\hline 27 & Basic metals & 39 & 39 & 38 & 41 & 46 & 47 \\
\hline 28 & Fabricated metal & 32 & 39 & 43 & 36 & 40 & 48 \\
\hline 29 & Machinery & 38 & 40 & 42 & 44 & 48 & 52 \\
\hline 30 & Office machinery & 43 & 47 & 61 & 94 & 98 & 98 \\
\hline 31 & Electrical machinery & 58 & 68 & 70 & 75 & 77 & 77 \\
\hline 32 & Radio, TV & 32 & 26 & 39 & 60 & 76 & 83 \\
\hline 33 & Precision instruments & 33 & 37 & 45 & 41 & 48 & 43 \\
\hline 34 & Motor vehicles & 55 & 59 & 79 & 83 & 87 & 91 \\
\hline 35 & Transport equipment & 23 & 24 & 22 & 35 & 50 & 40 \\
\hline \multirow[t]{2}{*}{36} & Furniture & 27 & 28 & 43 & 41 & 40 & 43 \\
\hline & Total & 24 & 27 & 32 & 36 & 42 & 48 \\
\hline
\end{tabular}

Source: Statistical Yearbooks, CSO.

\subsection{The level of technology and changes in export structure}

If the technological level is taken into account, we see that the structure of production and export of the manufacturing industry changed remarkably between 1993 and 1998. The percentage share of the industrial subsectors that belong to high-tech industries increased from $12 \%$ to $22 \%$ in the output, and in exports from $20 \%$ to $33 \%$ due to the rapid growth of office machinery and telecommunications equipment, in particular.

The share of subsectors with medium level of technology also increased, from $25 \%$ to $33 \%$ in output and from $33 \%$ to $41 \%$ in exports. The key role was played by the manufacture of motor vehicles, because both its output and export multiplied between 1993 and 1998: its percentage share in exports increased from 9\% 
in 1993 to $25 \%$ in 1998 . $^{3}$ The growth of other (smaller) subsectors was also dynamic in this category; including the manufacture of plastic and rubber products, aluminum metallurgy, manufacture of several chemicals, to mention a few. Export growth exceeded output growth in the mid-tech industries, with the exception of two subsectors (casting of iron and steel and manufacture of pesticides and other agrochemicals).

Table 15

Share of subsectors in output and exports by the level of technology (\%)

\begin{tabular}{lcccr}
\hline \multirow{2}{*}{$\begin{array}{l}\text { Level } \\
\text { of technology }\end{array}$} & \multicolumn{3}{c}{1993} & \multicolumn{2}{c}{1998} \\
\cline { 2 - 5 } & Output & Exports & Output & Exports \\
\hline High tech & 12 & 19 & 22 & 34 \\
Medium tech & 25 & 34 & 33 & 41 \\
Low tech & 63 & 47 & 45 & 25 \\
Total & 100 & 100 & 100 & 100 \\
\hline
\end{tabular}

Source: Own calculations based on the CSO's database.

The weight of subsectors with low technological level decreased in 1993-1998, with respect to both output and export. However, it is interesting to note that export growth was faster than output growth even in most of these subsectors: textile, clothing, wearing apparel, wood and wood products, paper, fabricated metal.

If we compare export and output of Hungary and the developed countries, export performance is not so promising. At the beginning of the 1990s export per capita (in US\$) lagged behind that of the developed economies, and the difference was larger than in the case of the GDP. Despite the modernised export structure, the gap in the export performance did not narrow. In the 1990s in the small open EU economies - e.g. in Austria, the Netherlands, and Belgium - the GDP per capita was 5 times more than the corresponding Hungarian figure, whereas export was 6, 8 and 11 times the Hungarian export. Export reorientation meant the loss of "Eastern" markets and the gaining of "Western" markets, however, the export per capita of the small economies mentioned is still a multiple of the Hungarian performance.

3 It should be noted that some other classifications consider motor vehicle industry as a high-tech industry. 
Table 16

Share of exports in output in 1993 and 1998 by the level of technology (\%)

\begin{tabular}{|c|c|c|}
\hline & 1993 & 1998 \\
\hline High Technology & 46 & 81 \\
\hline Pharmaceuticals & 47 & 57 \\
\hline Office machinery & 44 & 98 \\
\hline Radio, TV sets & 31 & 83 \\
\hline Electrical machinery & 57 & 75 \\
\hline Medical precision instruments & 32 & 43 \\
\hline Medium technology & 38 & 66 \\
\hline Organic, inorganic, basic chemicals & 33 & 53 \\
\hline Plastics, synthetic rubbers & 47 & 59 \\
\hline Manufacturing of rubber products & 32 & 42 \\
\hline Manufacturing of plastic products & 26 & 35 \\
\hline Metallurgy of aluminum & 50 & 65 \\
\hline Casting of iron and steel & 44 & 38 \\
\hline Machinery and equipment & 37 & 53 \\
\hline Manufacturing of other transport equipment & 20 & 38 \\
\hline Motor vehicles, trailers & 55 & 90 \\
\hline Other manufacturing industry & 28 & 41 \\
\hline Pesticides and other agrochemicals & 47 & 46 \\
\hline Paints, varnishes & 11 & 13 \\
\hline Soap and detergents & 9 & 23 \\
\hline Low technology & 21 & 30 \\
\hline Food, beverages & 15 & 23 \\
\hline Tobacco & 5 & 9 \\
\hline Textile, clothing, leather & 36 & 56 \\
\hline Wearing apparel & 61 & 70 \\
\hline Leather, luggage, handbag & 46 & 63 \\
\hline Wood and wood products & 21 & 44 \\
\hline Paper & 9 & 28 \\
\hline Publishing, printing & 4 & 4 \\
\hline Manufacturing of of refined petroleum & 21 & 20 \\
\hline Other non-metallic minerals & 22 & 30 \\
\hline Iron and steel & 34 & 34 \\
\hline Fabricated metals & 32 & 47 \\
\hline Manufacturing of of other transport equipment & 20 & 38 \\
\hline Total & 24 & 48 \\
\hline
\end{tabular}

Source: CSO, Éltető (1999) and GKI Co. calculations.

\subsection{Import dependency of the Hungarian industry}

Hungarian economic development is traditionally import-dependent, but there have been significant changes in this respect. In 1993 import exceeded export by $42 \%$, and this figure was only $12 \%$ in 1998 . In the last five years (1994-1998) the growth of the volume of exports was 109\%, and the growth of the volume of im- 
ports was $83 \%$. Out of the 22 subsectors, the import per export ratio increased in eight industries and decreased also in eight between 1993 and 1998 (it did not change in six sub-branches). The import per export ratio increased in the following subsectors: manufacture of food products, textile, leather products, chemical products, building material, basic metal and the engineering industry. It decreased in the manufacture of paper, plastic products, fabricated metal, office machinery, telecommunications equipment, precision instruments, motor vehicles and furniture.

Table 17

Import/export ratio in 1993-1998

\begin{tabular}{llrl}
\hline $\begin{array}{l}\text { NACE } \\
\text { code }\end{array}$ & Sector & 1993 & 1998 \\
\hline 15 & Food & 0.40 & 0.47 \\
16 & Tobacco & 0.15 & 0.14 \\
17 & Textile & 1.93 & 2.16 \\
18 & Fur & 0.32 & 0.32 \\
19 & Leather & 0.81 & 1.02 \\
20 & Wood & 0.94 & 0.75 \\
21 & Paper & 5.06 & 2.91 \\
22 & Publishing and printing & 2.43 & 2.57 \\
24 & Chemical & 1.53 & 1.78 \\
25 & Plastic & 1.83 & 1.78 \\
26 & Non-metallic minerals & 0.95 & 1.15 \\
27 & Basic metals & 0.81 & 1.41 \\
28 & Fabricated metal & 1.54 & 1.37 \\
29 & Machinery & 1.95 & 2.12 \\
30 & Office machinery & 14.35 & 0.61 \\
31 & Electrical machinery & 0.76 & 0.77 \\
32 & Radio, TV & 1.75 & 1.29 \\
33 & Precision instruments & 3.08 & 2.28 \\
34 & Motor vehicle & 2.80 & 0.79 \\
36 & Furniture & 1.36 & 0.78 \\
& Total & 1.42 & 1.12 \\
\hline
\end{tabular}

Source: Calculations based on the foreign trade statistics 1993 and 1998, CSO.

The figures show that there were rather significant structural changes in certain sectors, in office machinery, for instance. In 1993, trade in the manufacture of office machinery was one-sided: the export was negligible compared to import. Due to the inflow of FDI, the production of office machinery and computers rose very rapidly, and in 1998 the export was 1.6 times larger than the import. To a smaller extent, but something similar happened in the manufacture of motor vehicles and in other subsectors as well. 
A research carried out in 1998 also supported import dependency with the use of 1993-1996 data. We found that the import-dependent subsectors of industry (which imported more than $47 \%$ of their output, the average at that time), were among the most significant exporters taking into account the export per output ratio.

\subsection{The impact of FDI on Hungarian industry and trade}

In the following, we would like to deliver some of the findings of the research referred to in the Introduction. The investigations were carried out in the framework of an international research project (Viszt-Borsi, 1998). Although the time series corresponded to the 1993-1996 period, the findings regarding the role of FDI in foreign trade are relevant for the discussed period as well. ${ }^{4}$

The Central and Eastern European Countries attracted substantial amount of foreign capital in the last decade (from 1992 continuously). As a result of FDI, foreign firms produce more than half of the manufacturing industry's output in Hungary and their role in the country's exports is even more significant. In the other CEECs (e.g. the Czech Republic, Poland and Slovenia) there is a considerable amount of foreign capital in the motor vehicle industry, the manufacture of rubber and plastic products, and electric and telecommunications equipment. In several sectors, where foreign firms perform exports, intra-firm trade plays an important role in foreign trade.

Several authors stress that the most sizable part of FDI is carried out by multinational companies (Konings, 1996). Usually they operate on oligopolistic markets with a limited number of actors. Konings distinguished two types of investments, the first being based on traditional comparative advantages (i.e. cheap labour). These ventures are of a smaller scale and perform labour-intensive production. As his case studies showed, most of the observed FDI were searching other advantages than wage costs, like the relatively easy penetration to new markets (Szanyi, 1998). Lakatos and Papanek (1994) distinguished the interests of investor companies. Some of them wanted to invest in order to capture the market or to increase the market share; others invested in order to establish strongly integrated processing facilities for sub-assemblies.

4 The database was compiled by the Central Statistical Office of Hungary. Upon our request, the output, employment, etc. data were provided in the same classification as the foreign trade data. This database, which was based on corporate balance sheets, provided us a new tool to analyse the structural changes of the economy. 
With regard to export orientation, foreign companies also have to be segmented. Case studies proved that companies that perform only assembling depended highly on export and import. Companies that realised FDI based on domestic suppliers had lower weight of imported inputs. Our investigations showed that companies with foreign participation play an increasingly important role in the export of all industries.

Table 18

Share of companies with foreign participation in exports by industries

\begin{tabular}{|c|c|c|c|c|}
\hline \multirow{2}{*}{ Sector } & \multicolumn{4}{|c|}{ Export of foreign companies / export total of the sector (\%) } \\
\hline & 1993 & 1994 & 1995 & 1996 \\
\hline Food & 57 & 59 & 59 & 64 \\
\hline Textile & 52 & 55 & 62 & 65 \\
\hline Fur & 49 & 49 & 51 & 49 \\
\hline Leather & 42 & 55 & 52 & 56 \\
\hline Wood & 44 & 43 & 64 & 70 \\
\hline Paper & 80 & 80 & 82 & 76 \\
\hline Publishing and printing & 37 & 33 & 43 & 39 \\
\hline Energy & n.a. & n.a. & n.a. & n.a. \\
\hline Chemical products & 34 & 51 & 90 & 95 \\
\hline Plastic & 61 & 63 & 61 & 61 \\
\hline Non-metallic minerals & 63 & 70 & 82 & 74 \\
\hline Metallurgy & 15 & 26 & 24 & 51 \\
\hline Fabricated metals & 62 & 70 & 69 & 51 \\
\hline Machinery & 48 & 65 & 63 & 71 \\
\hline Office machinery & 83 & 74 & 78 & 97 \\
\hline Electric machinery & 92 & 93 & 95 & 96 \\
\hline Radio, TV & 60 & 62 & 79 & 91 \\
\hline Instruments & 47 & 58 & 57 & 66 \\
\hline Motor vehicles & 67 & 78 & 89 & 90 \\
\hline Transport equipment & 78 & 75 & 70 & 63 \\
\hline Furniture & 41 & 54 & 68 & 65 \\
\hline Total & 48 & 57 & 68 & 77 \\
\hline
\end{tabular}

Source: Corporate balance sheets, CSO's database.

In Hungary, the foreign share in the registered capital of firms is rather high, in many subsectors it is above $50 \%$. In nine sectors there is more foreign capital than the average: the food industry, manufacture of tobacco products, wood industry, chemical industry, manufacture of rubber and plastic products, manufacture of other non-metallic mineral products, manufacture of basic metals, manufacture of office machinery and computers, manufacture of electrical machinery and apparatus, and manufacture of motor vehicles. Foreign capital attained at least a 25\% share in all of the industries. 
Employment in the (at least partly) foreign companies is steadily increasing. The next table summarises the sectoral employment ratios of the companies that had at least $10 \%$ foreign capital in the registered capital. In the manufacture of "other transport equipment", foreign companies employ more than half of the sector's labour force.

Table 19

Share of companies with foreign participation in employment (\%)

\begin{tabular}{|c|c|c|c|c|}
\hline Sector & 1993 & 1994 & 1995 & 1996 \\
\hline Food & 35 & 38 & 41 & 36 \\
\hline Textile & 22 & 27 & 29 & 28 \\
\hline Fur & 26 & 28 & 29 & 27 \\
\hline Leather & 22 & 31 & 29 & 30 \\
\hline Wood & 15 & 14 & 21 & 23 \\
\hline Paper & 50 & 46 & 44 & 44 \\
\hline Publishing and printing & 21 & 23 & 24 & 22 \\
\hline Coke, etc., nuclear fuel & 0 & 0 & 0 & 0 \\
\hline Chemical & 34 & 43 & 89 & 90 \\
\hline Plastic & 28 & 33 & 33 & 35 \\
\hline Non-metallic minerals & 39 & 40 & 47 & 43 \\
\hline Basic metals & 10 & 12 & 11 & 21 \\
\hline Fabricated metal & 21 & 24 & 25 & 25 \\
\hline Machinery & 22 & 27 & 29 & 21 \\
\hline Office machinery & 52 & 53 & 49 & 41 \\
\hline Electrical machinery & 63 & 63 & 68 & 71 \\
\hline Radio, TV & 26 & 33 & 41 & 43 \\
\hline Precision instruments & 24 & 31 & 27 & 30 \\
\hline Motor vehicles & 34 & 36 & 40 & 44 \\
\hline Transport equipment & 46 & 40 & 20 & 52 \\
\hline Furniture & 17 & 20 & 21 & 20 \\
\hline Total & 28 & 31 & 36 & 35 \\
\hline
\end{tabular}

Source: see Table 18.

The share of foreign companies is larger in output than in the registered capital. If we add the output of "foreign" firms, we find that except for six sectors (textile industry, manufacture of wearing apparel, wood industry, manufacture of rubber and plastic products, manufacture of other non-metallic mineral products, manufacture of basic metals) the share of foreign companies in output is larger than the share of foreign capital in the individual branches. Moreover, the share of the "foreign" companies is highly above in export than in the registered capital and except for three sectors (paper industry, manufacture of precision instruments, manufacture of other transport equipment), employment is lower than the foreign capital share. All this should imply that firms with foreign ownership, are more produc- 
tive than the others. ${ }^{5}$ This is especially true - in accordance with our research based on the corporate data for 1993-1996 - for the manufacture of wood products, machinery and equipment, and the manufacture of office machinery. In these sectors the percentage share of foreign capital is twice as high in output as in employment.

In 1996 there was only one sector (in NACE 2-digit breakdown) which exported less than $20 \%$ of its output. In general, the foreign owned companies are much more export-oriented than the average. The export per output ratio of companies with foreign participation was less than the average only in two sectors (the manufacture of wearing apparel and the leather industry).

More foreign capital in the registered capital seems to imply higher exports. Low export and high share of foreign capital in the given industry can occasionally mean that the foreign capital wanted to penetrate to the domestic markets despite the fact that the small size of the Hungarian market does not necessarily support this statement. This would mean that foreign capital is represented not only by large multinational companies, but by small companies as well.

\section{REFERENCES}

Adler, J., Viszt, E. et al. (1999a): A foglalkoztatás és az azt meghatározó folyamatok alakulása a 90-es évtizedben, a középtávon prognosztizálható tendenciák (Employment and Related Factors in the 90s and Mid-term Prognosis). Budapest: GKI Co.

Adler, J. and Viszt, E. (1999b): A gazdasági szerkezet alakulása 1992-1998 között (Changes of the Economic Structure in 1992-1998). Budapest: GKI Co.

Djankov, S. and Hoekman, B. (1996): Intra-Industry Trade, Foreign Direct Investment and the Reorientation of Eastern European Exports. CEPII Discussion Paper, No. 7377. Paris.

Dobrinski, R. (1996): Economic Transformation and the Changing Pattern of European East-West Trade. In: Dobrinski, R. and Landesmann, M.: Transforming Economies and European Integration. London: Edwar Elgar.

ECOSTAT (1998): Vállalatok Magyarországon (Companies in Hungary). Budapest: ECOSTAT.

Éltető, A. (1999): Foreign Direct Investments in Spain and Hungary: Main Patterns and Effects with a Special Regard to Foreign Trade. Budapest: MTA VKI.

GKI (1998): A kapitalizmus alapjainak lerakása Magyarországon (From Socialism to Capitalism in Hungary). Budapest: GKI Co.

Hüttl, A., Surányi, B. and Vita, L. (1998): A gazdasági növekedés és fejlettség paradoxona a közép-kelet európai átmenetben (The paradox of economic growth and the level of development in the transition of Central Eastern Europe). Közgazdasági Szemle, November.

5 Foreigners tried to acquire the more productive firms during privatisation. Nonetheless, they also strive more to be productive. 
Inotai, A. (1999): Magyarország és a többi közép- és kelet-európai ország szerkezeti átalakulása a Németországba irányuló export tükrében. 1989-1998 (Structural Changes in Hungary and Other Central and Eastern European Countries in the Mirror of their Exports to Germany). Budapest: MTA VKI.

Konings, J. (1996): Foreign Direct Investment in Transition Economies. Working Paper, No. 56. Leuven: Leuven Institute for Central and East European Studies.

Lakatos, B. and Papanek, G. (1994): Esettanulmányok a külföldi részvétellel alapított vállalatok motivációiról (Case-studies about Motivations for Establishing Enterprises with Foreign Participation in Hungary). Budapest: GKI Co.

Lemoine, F. and Freudenberg, M. (1998): CEECs in the International Division of Labour in Europe. Discussion Paper. Workshop "Trade between the EU and the Associated States: Prospects for the Future." CEPII. Paris, 26 November.

Molnár L. and Skultéty, L. (1999): A beruházások alakulása 1993-1998 között (The investments between 1993-1998). Közgazdasági Szemle, December.

Papanek, G., Petz, R., Török, Á., Ványai, J. and Viszt, E. (1998): A magyar exportstruktúra átalakulása és a $K+F$ intenzitás kapcsolata (The Change of Hungarian Export Structure and its Relation with R\&D Intensity). Budapest: GKI Co.

Szanyi, M. and Szemlér, T. (1997): Investment Patterns in Hungary, 1989-1995. Budapest: MTA VKI.

Szanyi, M. (1998): The Role of FDI in Restructuring and Modernising Transition Economies: An Overview of the Literature in Hungary. WIIW, No. 244, April.

Viszt, E. and Borsi, B. (1998): Structural Changes in the Hungarian Industry and Foreign Trade between 1993 and 1998. Budapest: GKI Co. (Paper prepared in the framework of ACE project "Trade between the EU and the Associated States: Prospects for the Future".) 